\title{
PENGEMBANGAN MODUL ANATOMI REPTIL DI DAERAH ALIRAN SUNGAI MAOSPATI MAGETAN UNTUK MENINGKATKAN PEMAHAMAN KONSEP MATA KULIAH STRUKTUR HEWAN DI IKIP PGRI MADIUN
}

\author{
Daniel Sugiarto \\ Pendidikan Biologi FPMIPA, IKIP PGRI Madiun \\ e-mail: danielsugiartoz@gmail.com
}

\begin{abstract}
During this time the students learning system, especially on the structure of animals in biology education IKIP PGRI MADIUN. information presented in the form of modules still no or less so difficult to accept students in particular about the material or preparations that are less known as well as local reptile anatomy that is found around the neighborhood students. The aim of developing local reptile anatomy modules in subjects animal structure. Research using 4-D model of development (Define, Design, Develop, Disseminate). Results of development in the form of draft module to be tested and improved understanding of the concept of students. The trial results are obtained material content of the course structure validator experts percentage of $86.66 \%$ was obtained animals can be categorized valid (good). The trial results stating that: 1 ) the modules worth diujicabakan field and very helpful in learning the anatomy of reptiles 2) Students are more familiar with preparations anatomy reptiles as obtained from the student environment and the result of understanding the concept of students with test pre test and posh test through the test $\mathrm{T}$ is obtained thitung 15.22> ttable 1,717 or able to enhance student understanding of concepts. Limitations modules developed only compiled on the subject of local reptile anatomy.
\end{abstract}

Keywords: anatomy of local reptiles, modules, understanding concept

\section{PENDAHULUAN}

Proses pembelajaran matakuliah struktur hewan di program studi pendidikan biologi FPMIPA IKIP PGRI Madiun informasi yang ditampilkan dalam bentuk buku maupun modul masih belum ada atau kurang. Buku teks yang ada kebanyakan masih berbahasa asing sehingga untuk pemahaman konsep matakuliah struktur hewan masih sulit diterima mahasiswa khususnya tentang materi atau preparat yang kurang dikenal. Materi yang ditampilkan dalam buku seperti halnya anatomi reptil tidak semuanya dikenal oleh mahasiswa, sehingga mahasiswa kesulitan memahami konsepnya. Pemilihan preparat lokal yang di temukan di sekitar wilayah tempat tinggal mahasiswa dapat membantu menjelaskan konsep yang selama ini kurang dipahami. Penelitian ini bertujuan untuk mengembangkan produk berupa modul melalui anatomi reptil di daerah aliaran sungai Maospati magetan untuk meningkatkan pemahaman konsep mata kuliah struktur hewan

Tujuan modul menurut Majid (2013), pembelajaran dengan modul memungkinkan peserta didik yang memiliki kecepatan tinggi dalam belajar akan lebih cepat menyelesaikan satu atau lebih kompentensi dasar dibandingkan dengan peserta didik lainya. Modul adalah bahan ajar yang dapat membimbing peserta didik secara mandiri yang mampu. menyelesaikan tujuan-tujuan tertentu yang berisi materi pelajaran, metode belajar, 
alat, sumber dan sistem evaluasi (Wibowo, 2012).

Menurut Dharma (2008) penulisan modul memiliki tujuan memperjelas dan mempermudah penyajian pesan agar tidak terlalu bersifat verbal, mengatasi keterbatasan waktu, ruang, dan daya indera, baik peserta belajar maupun guru/instruktur, dapat digunakan secara tepat dan bervariasi, seperti untuk meningkatkan motivasi dan gairah belajar; mengembangkan kemampuan dalam berinteraksi langsung dengan lingkungan dan sumber belajar lainnya yang memungkinkan siswa atau pebelajar belajar mandiri sesuai kemampuan dan minatnya, memungkinkan siswa atau pembelajar dapat mengukur atau mengevaluasi sendiri hasil belajarnya (Harijanto, 2007). Ciri-ciri modul menurut
Sari dkk (2014) modul didahului oleh pernyataan sasaran belajar, pengetahuan disusun sedemikian rupa sehingga dapat menggiring partisipasi peserta didik secara aktif, memuat sistem penilaian berdasarkan penguasaan, memuat semua unsur bahan pelajaran dan semua tugas pelajaran, memberi peluang bagi perbedaan antar individu mahasiswa, mengarah pada suatu tujuan belajar tuntas.

Modul yang dikembangkan disusun secara kontekstual dengan menyajikan berdasarkan penelitian yang telah dilakukan di daerah aliran sungai Maospati Magetan. Hasil penelitian diperoleh 1 jenis Ordo Squmata terdiri dari 3 jenis spesies yaitu Bronchocela jubata (Bunglon), Gekko gecko (Tokek) dan Mabouya multifisciata (Kadal) dapat dilihat pada Gambar 1.

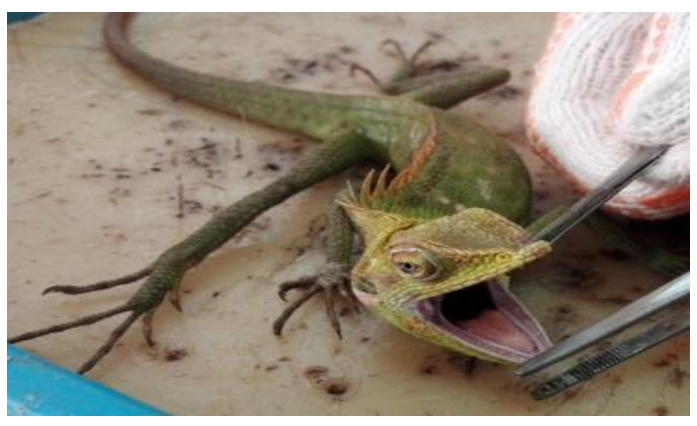

Gambar 1. Bronchocela jubata

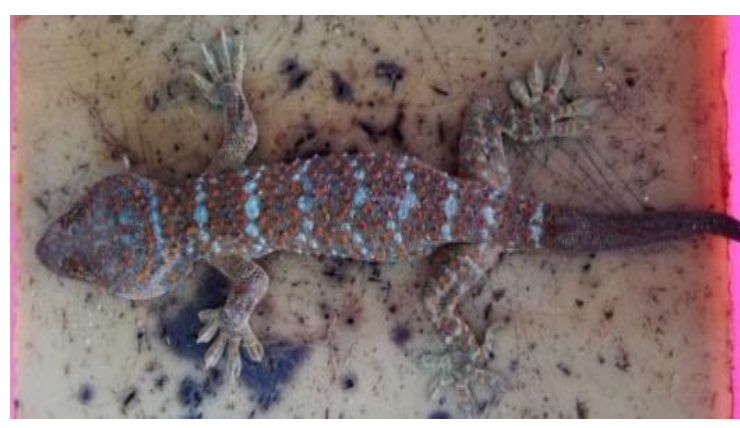

Gambar 2. Gekko gecko

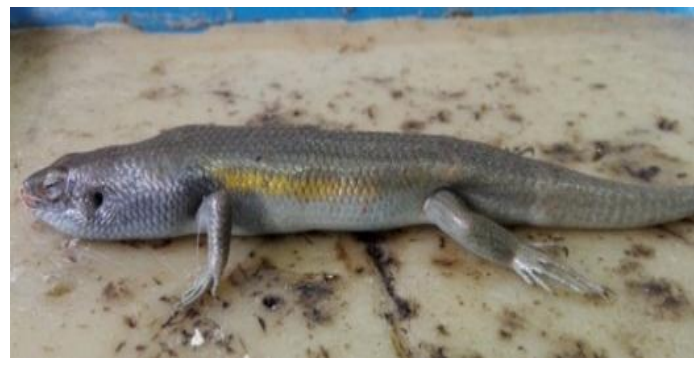

Gambar 3 Mabouya multifisciata

Hasil penelitian diperoleh dari daerah aliran sungai Maospati Magetan didokumentasikan melalui foto yang digunakan untuk menyusun modul yang bersifat kontekstual. Reptil temuan hasil Penelitian dijadikan contoh faktual dalam modul yang memuat materi anotomi reptil yaitu: a) ciri-ciri reptil; b) ordo pada kelas reptil; c) skelekton reptil; d) deskripsi reptil; e) habitat reptil; f) anatomi dan morfologi; g) sistem respirasi; h) sistem 
sirkulasi; i) sistem digestorium, j) sistem otot, k) uji Kompentensi.

\section{METODE PENELITIAN}

Desain penelitian menggunakan model pengembangan 4D Produk yang di kembangkan berupa modul anatomi reptil lokal yang terdiri dari (Define, Design, Development, Disseminationt) dari Thiagarajan, Semmel, dan Semmel (1974) (dalam Trianto, 2010). Uji coba produk penelitian dan pengembangan menggunakan desain uji coba dan jenis data deskriptif, instrumen pengumpulan data adalah lembar observasi berupa angket penilaian modul oleh ahli isi materi, dosen mata kuliah (Arifin, 2012), dan uji coba kelompok skala kecil dengan melibatkan 26 mahasiswa yang mengambil matakuliah struktur hewan. Data kuantitatif dari angket digunakan untuk mengolah data dalam bentuk kualitatif berdasarkan persentase keidealan dengan rumus sebagai berikut. Persentase keidealan:

$$
\text { Nilai }=\frac{\text { Skor jawaban benar }}{\text { Skor total }} \times 100
$$

Prosedur Pengembangan 4D pada tahap pendefinisian (define) meliputi analisis ujung depan, analisis mahasiswa, analisis konsep, perumusan tujuan pembelajaran.Tahap perancangan (design) meliputi penyusunan tes acuan patokan, memilih format, menentukan strategi evaluasi. Tahap pengembangan (develop) melalui dua langkah yaitu penilaian ahli yang di ikuti revisi dan uji coba pengembangan. Tahap penyebaran (disseminate) dilakukan melalui jurnal penelitian.

\section{HASIL DAN PEMBAHASAN}

Pengembangan modul menggunakan model pengembangan 4D yaitu (Define,
Design, Development, Disseminationt) Tahap dilakukan pada Selasa 5 Januari 2016 bertempat di ruang lab Biologi 2 penilaian modul oleh dosen matakuliah struktur hewan menujukan presentase keidealan $88,33 \%$ dengan katagori valid (baik) dan dari dosen ahli $85 \%$ dengan katagori valid (baik). Hasil coba pemahaman konsep mahasiswa dengan pre-test dan pos-test dilakukan uji $t$ diperoleh hasil $t_{\text {hitung }} 15,22>t_{\text {tabel }} 1,717$ hasil ini menujukan bahwa modul dapat meningkatkan pemahaman konsep mahasiswa. Komentar dari dosen pengampu matakuliah dan dosen ahli, modul yang dikembangkan sudah baik atau layak digunakan dalam pembelajaran mata kuliah struktur hewan karena materi diambil dari lingkungan sekitar yang sudah dikenal mahasiswa sehingga lebih mudah memahami konsep tentang reptil, modul memiliki kekurangan pada penulisan yang masih perlu untuk direvisi. Penggunaan model pengembangan 4D menunjukkan hasil yang baik dan layak digunakan dalam pembelajaran. Hasil penelitian juga di dukung dengan analisis literatur dari penelitian yang kontekstual sebagai produk pengembangan mampu meningkatkan hasil belajar mahasiswa.

\section{KESIMPULAN DAN SARAN}

\section{Simpulan}

Berdasarkan hasil penelitian dan pengembangan modul anatomi reptil yang merupakan hasil penelitian di daerah aliran sungai Maospati Magetan dapat dikatakan layak digunakan dalam pembelajaran struktur hewan pada materi antomi reptil. Modul mampu miningkatkan pemahaman konsep mahasiswa IKIP PGRI Madiun.

\section{Saran}

Pengembangan modul dapat dilakukan berdasarkan hasil penelitian dengan lokasi pengambilan data pada 
daerah yang lebih luas sehingga diperoleh jenis reptil yang lebih beragam, sehingga konsep mahasiswa tentang reptil lebih meluas.

\section{DAFTAR PUSTAKA}

Arifin, Z. (2012). Evaluasi Pembelajara Prinsip Teknik Prosedur. Bandung: Remaja Rosdakarya Offset

Dharma, S. (2008). Penulisan Modul. Jakarta: Buku (Online), (https://teguhsasmitosdp1.files.word press.com), diakses 29 Septembar 2015

Harijanto, M. (2007). Pengembangan Bahan Ajar Untuk Peningkatan Kualitas Pembelajaran Program Pendidikan Pembelajar Sekolah Dasar. Jurnal Didaktika Vol. 2 No 1 (Online) (http://utsusurabaya.files. wordpress.com), 14 Januari 2016.

Majid, A. (2013). Perencanaan Pembelajaran Mengembangkan standar Komptensi Guru. Bandung: PT Remaja Rosdakarya

Sari, I., dan Primiani N.C. (2014). Pengembangan Modul Identifikasi Arthropoda Darat dari Hutan Pitu Kabupaten Ngawi pada Mata Kuliah Taksonomi Invertebrata, Jurnal (Online) (http://prosiding.upgrismg.ac.id/), diakses 30 September 2015

Trianto. (2010). Model Pembelajaran Terpadu Konsep, Strategi, Dan Implementasi Dalam Kurikulum Tingkat Satuan Pendidikan (KTSP). Jakarta: PT Bumi Aksara

Wibowo Haryo, P. (2012). Pengaruh Penggunaan Modul Hasil Penelitian Bentos Pada Pokok Bahasan Pencemaran Lingkungan Terhadap Keterampilan Proses Sains Siswa
Kelas X SMANegeri 1 Mojolaban Tahun Pelajaran 2011/2012, Jurnal (Online) (www.undana.ac.id) diakses 29 September 2015 